\title{
Energetic costs to the Eastern oyster Crassostrea virginica due to recent parasitism by the ectoparasitic gastropod Boonea impressa*
}

\author{
Laurence D. Gale ${ }^{1, * *}$, John J. Manzi ${ }^{2}$, Michael P. Crosby ${ }^{3, * * *}$ \\ ${ }^{1}$ College of Charleston, Grice Marine Biological Laboratory, 205 Fort Johnson, Charleston, South Carolina 29412, USA \\ ${ }^{2}$ International Mariculture Resources, 1725 Signal Point Road, Charleston, South Carolina 29412, USA \\ ${ }^{3}$ Belle W. Baruch Institute for Marine Biology and Coastal Research, University of South Carolina, Baruch Marine Field \\ Laboratory, PO Box 1630, Georgetown, South Carolina 29442, USA
}

\begin{abstract}
Changes in the energy budget of the Eastern oyster Crassostrea virginica (Gmelin) due to metabolic alterations induced by Boonea impressa (Say) parasitism were analyzed using physiological and static measurements. Results showed that past parasitism by $B$. impressa caused no significant longterm metabolic stress to oysters during periods of high food availability. $B$. impressa did not have a significant negative impact on oyster net production, clearance rate, respiration rate, ammonia excretion rate, gamete production, Perkinsus marinus infection intensity, nor condition index during the parasitism experiment. Shell deposition rates were significantly $(p<0.01)$ reduced in oysters that had previously been parasitized by $B$. impressa. However, these same oysters had a significantly $(p<0.01)$ greater net production rate $\left(\mathrm{J} \mathrm{h}^{-1}\right)$ after pararsitism. Data presented here support the premise that available energy, particulate inorganic and particulate organic matter can ultimately determine the ecological significance of $B$. impressa parasitism in oysters. Although previous studies have indicated that ecto-parasitism can be highly deleterious to oyster populations that are at or near limiting seston concentrations, no evidence was found in this study to suggest that significant decreases in shell deposition rates in oysters that had previously been highly parasitized by $B$. impressa were correlated with decreases in net production. In contrast, our results support the hypothesis that decreases in shell deposition rates are attributed more to physical hindrance and shell breakage rather than to diversions of energy already assimilated by C. virginica.
\end{abstract}

\section{INTRODUCTION}

The Eastern oyster Crassostrea virginica inhabits inter- and sub-tidal regions along the eastern and Gulf coasts of the USA (Galstoff 1964). As early as the 1940s, oyster beds in the Gulf of Mexico were shown to exhibit high mortalities (Mackin \& Wray 1950, 1952) in response to infection by the protistan parasite Perkinsus marinus (Apicomplexa: Perkinsea), first identified

- Grice Marine Biological Laboratory Contribution \# 96; Baruch Institute Contribution \# 860

Present addresses:

- Michael Baker Jr, Inc., Airport Office Park, Building 3, 5th Floor, 420 Rouser Road, Coraopolis, Pennsylvania 15108, USA

-. Sanctuaries and Reserves Division, OCRM/NOS/NOAA, 1825 Connecticut Avenue, N.W., Suite 714, Washington, D.C. 20235 , USA by Mackin et al. (1950). Since the late 1940s this parasite has been documented in infected oysters from the Chesapeake Bay (Andrews 1955, 1965, 1967, 1980), South Carolina (Burrell et al. 1984, Scott et al. 1985, Crosby \& Roberts 1990), Florida (Quick \& Mackin 1971), and along the Gulf Coast (Ray 1954, Sprague 1954, Mackin 1962, Perkins 1976). Due to dwindling stocks of wild oysters in these areas, the distribution and mode of dispersion of $P$. marinus has been a concern of resource managers and researchers (Andrews 1988, Andrews \& Ray 1988). Recent studies suggest that the ectoparasitic gastropod Boonea impressa, which can also be infected with $P$. marinus, may serve as a vector in transmitting the disease from one oyster or oyster bed to another (White et al. 1987) and may also significantly depress growth rates in oysters (White et al. 1984, 1988a, Ward \& Langdon 1986, Powell et al. 1987a). Other studies examining taurine-to- 
glycine ratios indicate a change in the oyster's physiological response to its environment when parasitized by $B$. impressa and infected with $P$. marinus (Soniat \& Koenig 1982, White et al. 1988b). In the wild, densities of up to $100 \mathrm{~B}$. impressa per oyster have been observed (Hopkins 1956), with 20 to 40 snails on one oyster being not uncommon (pers. observ.). The infecting abilities and stress-induced parasitism by $B$. impressa may act in a synergistic manner to weaken the oyster. One possible consequence of parasitism by $B$. impressa (in addition to providing a source for $P$. marinus infection) is to make oysters increasingly susceptible to other environmental stress factors (e.g. pollution from industrial effluents, secondary pathogens, extremes in environmental parameters, etc.).

Laboratory studies conducted by Ward \& Langdon (1986) suggest that Boonea impressa may physically interfere with oyster valve movement, thereby limiting the oyster's ability to feed, or, by the snail's mode of feeding, extract energy already assimilated by Crassostrea virginica. White et al. (1988a) and Choi et al. (1989) have devised energetic models for the oyster that take into account B. impressa feeding and Perkinsus marinus parasitism, respectively. Both are based on laboratory, mathematical (Powell \& Stanton 1985) and field data. White et al. (1988a) believe that B. impressa may alter the energy balance of $C$. virginica, thereby disrupting the energy flow within the oyster reef community. Choi et al. (1989) hypothesize that decreases in shell growth and reproductive output exhibited in oysters parasitized by $P$. marinus in the Gulf of Mexico are due to a persistent drain on the oyster's assimilated energy by the parasite. To date there are few studies looking specifically at the potential impact a parasite may have on the scope-for-growth of its host (Newell \& Barber 1988). Newell (1985) studied the effects of the parasite Haplosporidium nelsoni (MSX) on the condition index, filtration, and respiration rate of $C$. virginica and reported empirical evidence that this parasite may stress its host by causing decreased filtration rates in infected oysters.

The objective of our study was to estimate stress in oysters recently parasitized by Boonea impressa. Stress was measured as a function of potential physiological change relative to the density of $B$. impressa parasitism by: (1) scope-for-growth (the energy status of an oyster); (2) assimilation efficiency (the efficiency with which an oyster converts food into body tissue); (3) oxygen:nitrogen ratios (measures of the balance between catabolic processes); and (4) body condition indices (alterations in the nutritional state of an oyster). In addition, synergistic influences on susceptibility to Perkinsus marinus infection and the effect that snail parasitism may have on shell deposition rates were also examined.

\section{MATERIALS AND METHODS}

Oyster larvae were allowed to settle and metamorphose on $1.2 \mathrm{~cm}$ diameter PVC pipe stakes in Charleston Harbor estuary (South Carolina, USA) from July 15 to July 17,1988 . The stakes were then transferred to shrimp ponds free of the ectoparasitic gastropod Boonea impressa, at the Waddell Mariculture Center, Bluffton, South Carolina. On March 14, 1989, oysters were randomly removed from the stakes, cleaned of all epibionts and transported to the South Carolina Marine Resources Research Institute (MRRI), Charleston. Oysters $(80$ to $100 \mathrm{~mm})$ were then acclimated for $10 \mathrm{~d}$ within experimental isolation chambers placed in a large flow-through tank. All seawater utilized in this study was continuously pumped from Charleston Harbor at the MRRI. Adult B. impressa were collected from an oyster reef adjacent to the Grice Marine Biological Laboratory, Charleston, on March 23, 1989. They were enclosed in $8.8 \mathrm{~cm}$ screened PVC chambers housed in upwelling tanks and allowed to feed on local oysters until used in the parasitism experiment.

The experimental design consisted of isolating individual oysters within chambers made of PVC pipe ( $8.8 \mathrm{~cm}$ diameter $\times 10.1 \mathrm{~cm}$ length) fitted within $80 \mathrm{l}$ glass aquaria. Fourteen PVC chambers were fitted within each aquarium using $1.8 \mathrm{~cm}$ plywood sheets $(2$ per aquarium) running in parallel the length of each aquarium. Holes $(8.8 \mathrm{~cm})$ were drilled in the plywood (14 per aquarium, 7 per side) $5 \mathrm{~mm}$ from the bottom to house each isolation chamber. The plywood barrier acted as a baffle, forcing $180 \mu \mathrm{m}$ filtered sea water from the top outer walls of each aquarium through the isolation chambers and passively out through a hole that was drilled in the upper top-center section of each aquarium. Gravity-fed water flowed (ca 1.7 to 2.01 $\mathrm{min}^{-1}$ ) to each aquarium from a 2501 passive settling tank. Equal water flow to each aquarium was regulated using adjustable $12.6 \mathrm{~mm}$ PVC ball valves.

Following the acclimation period, oysters $(\mathrm{N}=120)$ were placed in $8.8 \mathrm{~cm} \times 10.1 \mathrm{~cm}$ PVC flow-through isolation chambers and randomly assigned 1 of 4 treatments. All oysters from each treatment (each $\mathrm{n}=30$ ) were initially measured for shell height, and immersed (Andrews 1961) and emersed live weights. These same measurements were taken weekly thereafter coincident with cleaning of the isolation chambers for all treatments. A total of 4 experimental treatments were used. Treatments consisted of 2 unparasitized controls (Treatment $\mathrm{A}=$ unscreened; Treatment $\mathrm{B}=$ screened), 10 (Treatment $\mathrm{C}=$ screened) and 30 (Treatment $\mathrm{D}=$ screened) Boonea impressa per oyster respectively. To minimize any effects due to spatial heterogeneity, oysters were randomly assigned a treatment (i.e. A, B, C, or D) and randomly assigned a location (1 to 14) within 
each aquarium. Twelve oysters from each treatment, picked at random initially, were subjected successively to scope-for-growth analysis prior to and immediately after the 1 mo parasitism experiment. The calculation of scope-for-growth required measuring 4 physiological processes: clearance rate, food absorption efficiency, respiration rate, and excretion rate. Standardized methods and conversion of all physiological measurements into energy equivalents [ $\mathrm{J}(\mathrm{g} \text { dry } \mathrm{wt})^{-1} \mathrm{~h}^{-1}$ ], as outlined by Bayne et al. (1985), were followed.

Clearance rates were determined 3 times during each scope-for-growth analysis by collecting sea water (for $3 \mathrm{~min}$ intervals) with $400 \mathrm{ml}$ beakers at the outflow of each experimental feeding chamber. Particle concentrations for each sample were measured in triplicate, using a Coulter Counter (model ZB) with the sensitivity set for particles larger than $4 \mu \mathrm{m}$. Because body size can affect most physiological processes, all individual rates were corrected to a population mean standard body size using least squares regression analysis for the allometric equation:

$$
Y_{\mathrm{o}}=a X_{\mathrm{o}}{ }^{b}
$$

in which $Y_{\mathrm{o}}=$ standardized clearance rate $\left(1 \mathrm{~h}^{-1}\right) ; X_{\mathrm{o}}=$ measured dry body weight of the oyster $(\mathrm{g})$; and $a$ and $b=$ the intercept and slope for the regression of $\mathrm{N}=48$ oysters. This general equation was used to determine standardized rates for all physiological processes measured in this experiment.

Immediately after a clearance rate was taken, a known volume of filtered sea water $(110 \mu \mathrm{m})$ was filtered through a washed, ashed (muffled at $450^{\circ} \mathrm{C}$ for $2 \mathrm{~h}$ ) and preweighed $4.25 \mathrm{~cm}$ GFC glass fiber filter. Controls and samples were done in triplicate, washed of salts using ammonium formate $(34 \%)$, and frozen at $-20^{\circ} \mathrm{C}$. Controls and seston filter samples were oven dried at $90^{\circ} \mathrm{C}$ for $48 \mathrm{~h}$ and weighed on a Mettler 4000 balance $( \pm 5.0 \mu \mathrm{g}$ ) to calculate the total dry weight of particulate matter per liter of seawater. Filters were then ashed at $450^{\circ} \mathrm{C}$ (ca $2 \mathrm{~h}$ ) in a muffle furnace and reweighed in order to calculate the weight of particulate organic matter (POM) or ashfree material. All transportation of filters after initial weighing and drying at $90^{\circ} \mathrm{C}$ was done using a desiccator. Feces and pseudofeces were collected separately throughout each analysis using a $2 \mathrm{ml}$ disposable pipette. At the end of each analysis sea water was removed from the samples and bottled samples were fixed with ammonium formate $(34 \%)$ and stored at $-20^{\circ} \mathrm{C}$. Samples were transferred to $4.25 \mathrm{~cm}$ GFC filters and analyzed with the same procedures as for POM. Absorption efficiency, which represents the efficiency by which an oyster absorbs material cleared from suspension, was calculated using the Conover ratio (Conover 1966). This method assumes that only the organic (POM) component of food was affected by the digestive process.
Oyster respiration was measured continuously over a 45 to 60 min period using a Strathkelvin $\mathrm{O}_{2}$ meter with a Radiometer $\mathrm{O}_{2}$ electrode fitted into a modified Quickfit Flask used as a respiration chamber. Oxygen consumption rate for each oyster was corrected to a mean standard body size using regression equations derived from pre- and post-parasitism data. After the previous scope-for-growth parameters had been measured, the shell control, blank control and experimental oysters were placed in individual beakers containing $500 \mathrm{ml}$ of membrane-filtered (Millipore filter, $0.2 \mu \mathrm{m}$ ) oxygenated seawater. Following a $2 \mathrm{~h}$ incubation period at room temperature, $20 \mathrm{ml}$ samples were taken from the beakers and analyzed for ammonia $\left(\mathrm{NH}_{4}-\mathrm{N}\right)$ in triplicate with a Technicon Autoanalyzer using a modification to the phenol-hypochlorite method of Solorzano (1969). Samples, measured in $\mu g$-at. $\mathrm{N}^{-1}$, were then corrected to a mean standard body size.

In addition to the scope-for-growth analysis, 3 other physiological indices were calculated. Net growth efficiency $\left(\mathrm{K}_{2}\right)$ measures the relative efficiency with which food is converted into body tissues and was calculated as a ratio of assimilated:absorbed energy (Thompson \& Bayne 1974). Oxygen to nitrogen ratio (O:N) is the calculated ratio of oxygen consumed to ammonia-nitrogen excreted (in atomic equivalents) and is an index of the relative utilization of protein versus carbohydrate and lipids in energy metabolism. Body condition index (CI) was calculated using the gravimetric technique as described by Crosby \& Gale (1990) and is an index of the nutritive condition of the oysters.

Perkinsus marinus analyses were performed using excised gill and rectum samples using the methods of Ray $(1953,1954,1966)$. Infection intensity level for each sample was assigned on a scale from 0 to 6 as described by Quick \& Mackin (1971), where $0=$ no hypnospores per whole sample and 6 is $\geq 1001$ hypnospores per 5 $\mathrm{mm}^{2}$ sample. Tissue explant size and slide preparation were kept as constant as possible. Shell deposition rates were measured prior to the acclimation period and weekly, thereafter, during the parasitism period by removing oysters from their isolation chambers, allowing them to air-dry (ca $1 \mathrm{~h}$ ), and then weighing in air and underwater. The acclimation period was used as the initial shell deposition rate prior to Boonea impressa parasitism. Following the 1 mo experiment, each oyster was sacrificed, measured, weighed, and analyzed for $P$. marinus infection intensity and body $\mathrm{CI}$.

\section{STATISTICAL ANALYSES AND RESULTS}

For all comparisons, treatments were tested for homogeneity of variance, kurtosis, and skewness (Sokal \& Rohlf 1981). If significant departures were 
Table 1. Crassostrea virginica. A comparison of treatment populations prior to and after parasitism for clearance rate $\left(\mathrm{CR} \mathrm{l} \mathrm{h}^{-1}\right)$, particulate organic matter (POM; $\left.\mathrm{mg} \mathrm{l}^{-1}\right)$, assimilation efficiency $\left(\mathrm{e}_{\mathrm{i}} \%\right)$, respiration rate $\left[V_{\mathrm{O}_{2}} ; \mathrm{ml}(\mathrm{g} \mathrm{dry} \mathrm{wt})^{-1} \mathrm{~h}^{-1}\right]$, ammonia

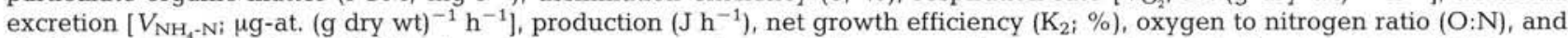

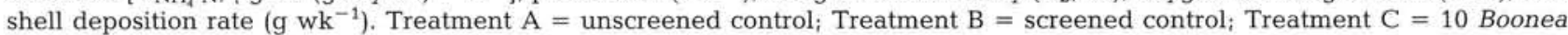
impressa per oyster; and Treatment $\mathrm{D}=30 \mathrm{~B}$. impressa per oyster. Included are standard errors (SE) for each treatment mean

\begin{tabular}{|c|c|c|c|c|c|}
\hline & $\begin{array}{l}\text { Pre-parasitism } \\
\text { control }\end{array}$ & $\begin{array}{c}\text { Post-treatment } \\
\text { A }\end{array}$ & $\begin{array}{c}\text { Post-treatment } \\
\text { B }\end{array}$ & $\begin{array}{c}\text { Post-treatment } \\
\text { C }\end{array}$ & $\begin{array}{c}\text { Post-treatment } \\
\text { D }\end{array}$ \\
\hline $\begin{array}{c}\mathrm{CR}^{\mathrm{a}} \\
\mathrm{SE}\end{array}$ & $\begin{array}{c}3.82 \\
( \pm 0.16)\end{array}$ & $\begin{array}{c}3.55 \\
( \pm 0.24)\end{array}$ & $\begin{array}{c}4.31 \\
( \pm 0.16)\end{array}$ & $\begin{array}{c}4.76 \\
( \pm 0.31)\end{array}$ & $\begin{array}{c}3.57 \\
( \pm 0.31)\end{array}$ \\
\hline $\begin{array}{l}\mathrm{POM}^{\mathrm{a}} \\
\mathrm{SE}\end{array}$ & $\begin{array}{c}3.38 \\
( \pm 0.27)\end{array}$ & $\begin{array}{c}2.74 \\
( \pm 0.18)\end{array}$ & $\begin{array}{c}3.28 \\
( \pm 0.58)\end{array}$ & $\begin{array}{c}3.08 \\
( \pm 0.23)\end{array}$ & $\begin{array}{c}10.07^{\mathrm{A}} \\
( \pm 2.02)\end{array}$ \\
\hline e & 63.82 & 60.78 & 50.74 & 67.46 & 44.37 \\
\hline SE & - & - & - & - & - \\
\hline $\begin{array}{c}V_{\mathrm{O}_{2}}{ }^{\mathrm{a}} \\
\mathrm{SE}\end{array}$ & $\begin{array}{c}0.987^{\mathrm{A}} \\
( \pm 0.046)\end{array}$ & $\begin{array}{c}1.118^{\mathrm{AB}} \\
( \pm 0.094)\end{array}$ & $\begin{array}{c}1.099^{\mathrm{AB}} \\
( \pm 0.081)\end{array}$ & $\begin{array}{c}1.071^{\mathrm{AB}} \\
( \pm 0.077)\end{array}$ & $\begin{array}{c}1.235^{\mathrm{B}} \\
( \pm 0.191)\end{array}$ \\
\hline $\begin{array}{l}V_{\mathrm{NH}_{4}-\mathrm{N}^{\mathrm{a}}} \\
\mathrm{SE}\end{array}$ & $\begin{array}{c}5.542^{\mathrm{A}} \\
( \pm 0.602)\end{array}$ & $\begin{array}{c}4.375^{\mathrm{AB}} \\
( \pm 0.843)\end{array}$ & $\begin{array}{c}1.445^{\mathrm{BC}} \\
( \pm 0.321)\end{array}$ & $\begin{array}{c}1.325^{\mathrm{C}} \\
( \pm 0.281)\end{array}$ & $\begin{array}{c}2.89^{\mathrm{A}} \\
( \pm 0.843)\end{array}$ \\
\hline $\begin{array}{l}\text { Production }^{\mathrm{a}} \\
\text { SE }\end{array}$ & $\begin{array}{c}171.80^{\mathrm{A}} \\
( \pm 14.59)\end{array}$ & $\begin{array}{l}116.08^{\mathrm{A}} \\
( \pm 9.54)\end{array}$ & $\begin{array}{l}146.19^{\mathrm{AB}} \\
( \pm 8.77)\end{array}$ & $\begin{array}{c}211.00^{\mathrm{B}} \\
( \pm 15.59)\end{array}$ & $\begin{array}{c}350.60^{\mathrm{C}} \\
( \pm 31.87)\end{array}$ \\
\hline $\begin{array}{l}\mathrm{K}_{2}(\%)^{\mathrm{b}} \\
\mathrm{SE}\end{array}$ & $\begin{array}{c}89.10^{\mathrm{A}} \\
( \pm 0.005)\end{array}$ & $\begin{array}{c}82.40^{\mathrm{B}} \\
( \pm 0.014)\end{array}$ & $\begin{array}{c}86.30^{\mathrm{AB}} \\
( \pm 0.009)\end{array}$ & $\begin{array}{c}90.00^{\mathrm{AC}} \\
( \pm 0.008)\end{array}$ & $\begin{array}{c}92.80^{\mathrm{C}} \\
( \pm 0.009)\end{array}$ \\
\hline $\begin{array}{l}\mathrm{O}: \mathrm{N}^{\mathrm{a}} \\
\mathrm{SE}\end{array}$ & $\begin{array}{c}21.54^{\mathrm{A}} \\
( \pm 3.82)\end{array}$ & $\begin{array}{c}34.08^{\mathrm{AB}} \\
( \pm 15.10)\end{array}$ & $\begin{array}{c}77.40^{\mathrm{AB}} \\
( \pm 23.16)\end{array}$ & $\begin{array}{c}112.37^{\mathrm{B}} \\
( \pm 37.21)\end{array}$ & $\begin{array}{c}133.51^{\mathrm{B}} \\
( \pm 34.50)\end{array}$ \\
\hline $\begin{array}{l}\text { Shell }^{c} \\
\text { SE }\end{array}$ & $\begin{array}{c}0.540 \\
( \pm 0.042)\end{array}$ & $\begin{array}{c}0.551 \\
( \pm 0.035)\end{array}$ & $\begin{array}{c}0.667 \\
( \pm 0.031)\end{array}$ & $\begin{array}{c}0.482 \\
( \pm 0.031)\end{array}$ & $\begin{array}{c}0.225^{\mathrm{A}} \\
( \pm 0.023)\end{array}$ \\
\hline \multicolumn{6}{|c|}{$\begin{array}{l}\text { Results of Tukey's HSD multiple range test are presented as letters to the above right of treatment means. Analyses were } \\
\text { carried out on } \log _{10} \text {-transformed means. Each comparison was restricted to one set of } 5 \text { means listed horizontally. Different } \\
\text { letters (e.g. A vs B vs C) indicate significant differences between means }(\alpha=0.05) \text {. For production and } \mathrm{CR}, \mathrm{N}=48,12,12,12 \text {, } \\
12 ; \mathrm{POM}, \mathrm{N}=36,9,9,9,9 ; V_{\mathrm{O}_{2}}, \mathrm{~N}=25,6,8,6,12 ; \mathrm{O}: \mathrm{N}, \mathrm{N}=11,5,5,6,10 ; \text { and } \mathrm{NH}_{4}, \mathrm{~N}=21,8,8,9,10 \\
\text { b }{ }^{\mathrm{b}} \text { Results of Tukey's HSD multiple comparisons on arcsin-transformed means } \mathrm{N}=48,12,12,12,12 \\
{ }^{c} \text { Results of nonparametric multiple comparisons by stepwise test procedure }(\alpha=0.05) \mathrm{N}=120,30,30,30,30\end{array}$} \\
\hline
\end{tabular}

found (at $\alpha=0.05$ ), data were transformed and retested. If data still departed from normality and equal variance, nonparametric tests were performed.

Standardized clearance rates were examined prior to, and after parasitism using a fixed model 1-way analysis of variance (ANOVA; Sokal \& Rohlf 1981). Tukey's honestly significant difference (HSD) multiple range tests were performed to determine where significant differences in means of clearance rate existed. Analyses were carried out on $\log _{10}$-transformed data. The post-parasitism ANOVA tested the hypothesis that increasing densities of ecto-parasitism by Boonea impressa would not affect standardized clearance rate. No significant difference in mean clearance rate was measured for the 4 treatment populations (Table 1).

Particulate organic matter (POM, $\mathrm{mg}^{-1}$ ) was examined using a similar analysis as that for clearance rates. Since concentration of POM varied almost hourly, due to tidal influences, river runoff and weather, an ANOVA was done to test for differences in mean POM concentrations between the pre-experiment control and post-treatment groups. All analyses were done on $\log _{10}$-transformed data.

Values for POM varied during each tidal cycle and were generally lower during the flood tide and higher during ebb tide. This was attributed to increased organic loads from nearby rivers as the tide ebbed. Post-parasitism analysis of Treatment D demonstrates the significant $(p<0.01$ ) effect a preceding heavy rainfall during flood tide had on POM concentration (Table 1). There was no significant difference in POM concentration among the other treatments.

Individual oyster assimilation efficiencies were not determined in this experiment due to the difficulty in obtaining large enough samples of individual biodeposits. Therefore, feces and pseudofeces for each treatment population were pooled. The pooled average was used in calculating assimilation efficiency for each treatment (Table 1). Changes in assimilation efficiencies due to parasitism were not correlated. The relatively greater reduction in assimilation efficiency for 
treatment D after parasitism was attributed to significantly higher POM values after parasitism.

Standardized rates of oxygen consumption $\left[\mathrm{V}_{\mathrm{O}_{2}}\right.$; $\mathrm{ml} \mathrm{O}_{2}(\mathrm{~g} \text { dry } \mathrm{wt})^{-1} \mathrm{~h}^{-1}$ ] after the parasitism period was analyzed by the regression equation:

$$
\begin{gathered}
V_{\mathrm{O}_{2}}=0.031+0.421 \log (x) \\
\mathrm{r}=0.448,0.01<\mathrm{p}<0.05
\end{gathered}
$$

where $x=$ measured dry body weight $(\mathrm{g}) . V_{\mathrm{O}_{2}}$ were then tested using ANOVA on $\log _{10}$ data. The ANOVA tested the hypothesis that past ecto-parasitism by Boonea impressa had no effect on respiration rate. Results indicate that Treatment D had a significantly higher $(\mathrm{p}<0.01)$ respiration rate after the parasitism period (Table 1). However, Treatments A, B and C were not significantly different from that of Treatment $\mathrm{D}$ or the pre-parasitism control.

Rates of ammonia $\left[\mathrm{NH}_{4}-\mathrm{N} ; \mathrm{mg}(\mathrm{g} \text { dry } \mathrm{wt})^{-1} \mathrm{~h}^{-1}\right]$ excretion between the pre-parasitism control and postparasitism treatments were examined using ANOVA with Tukey's HSD to determine where significant differences in means existed. The hypothesis tested the idea that recent parasitism by Boonea impressa had no effect on ammonia excretion rates on oysters. No functional relationship was detected (regression analysis) for $\mathrm{NH}_{4}-\mathrm{N}$ with dry weight and shell height prior to and after the parasitism period. The reason for insignificant regression equations was due to the similar size of oysters used in the experiment and alternative routes of nitrogen loss (i.e. amino acid leakage and urea). Analyses indicate that ammonia excretion rates were generally lower after the parasitism period with Post-treatments $B$ and $C$ having significantly $(p<0.01)$ lower rates than that of the preparasitism control (Table 1).

Standardized net production rates were analyzed after parasitism using ANOVA on $\log _{10}$ data to test the hypothesis that increasing densities of Boonea impressa parasitism had no effect on net production rates. Results show that net production rate for Treatment D was significantly $(p<0.001)$ higher and Treatment A significantly $(\mathrm{p}<0.001)$ lower after parasitism (Table 1). Post-treatment B was similar to the pre-parasitism control and Post-treatments A and B while Posttreatment $\mathrm{C}$ was similar to the pre-parasitism control (Table 1).

Net growth efficiencies were analyzed after parasitism using 1-way ANOVA to test the hypothesis that past parasitism by Boonea impressa had no effect on net growth efficiency. Analyses were carried out on arcsine-transformed data. Results show that Post-treatment $\mathrm{D}$ was significantly $(\mathrm{p}<0.001)$ higher and Posttreatment A significantly $(\mathrm{p}<0.001)$ lower than the pre-parasitism control (Table 1). Post-treatment B was similar to both the pre-parasitism control and Posttreatment A, while Post-treatment $\mathrm{C}$ was similar to the pre-parasitism control and Post-treatment D (Table 1).

The ratio of oxygen consumed to ammonia excreted $(\mathrm{O}: \mathrm{N})$ was analyzed using 1-way ANOVA to test the hypothesis that increasing densities of past parasitism by Boonea impressa had no effect on O:N ratios. Analyses were done on $\log _{10}$ transformed data. Post-treatments C and D exhibited significantly $(\mathrm{p}<0.004)$ greater $\mathrm{O}: \mathrm{N}$ ratios than that of the pre-parasitism control while Post-treatments A and B were similar to the pre-parasitism control and Post-treatments $\mathrm{C}$ and D (Table 1).

A model-I 1-way analysis of variance (ANOVA) was used to test the hypothesis that there was no difference in condition index due to levels of Boonea impressa parasitism. Analyses were conducted on arcsine-transformed values. Means and standard errors (SE) of condition index $(\mathrm{CI})$ for treatments are given in Table 2. Results of a Kruskal-Wallis 1-way ANOVA for CI indicated no significant difference between treatments $(\mathrm{p}=0.145)$.

Weighted incidence (WI) of infection (Ray 1953), which represents a proportion of the population infected, and average infection intensity were calculated for each treatment population. A row by column

Table 2. Crassostrea virginica. Means $\left(\mathrm{N}=30\right.$ treatment $\left.^{-1}\right)$ and standard errors (SE) for treatment condition indices $(\mathrm{CI})$ and percent of total population infected and weighted incidence of infection (WI, Mackin Scale (0 to 6)) for gill and rectal samples from the original oyster population (prior to study) and the 4 treatments: Treatment $\mathrm{A}=$ unscreened-non-parasitized; Treatment $\mathrm{B}=$ screened-non-parasitized; Treatment $\mathrm{C}=10$ snails per oyster; Treatment $\mathrm{D}=30$ snails per oyster. See text for further

\begin{tabular}{|c|c|c|c|c|c|c|c|}
\hline & \multirow{2}{*}{$\begin{array}{c}\mathrm{CI} \\
\text { mean }\end{array}$} & \multirow[t]{2}{*}{ SE } & \multicolumn{2}{|c|}{ Gill } & \multicolumn{2}{|c|}{ Rectal } & \multirow[t]{2}{*}{$\mathrm{N}$} \\
\hline & & & $W T$ & $\%$ infected & $W I$ & $\%$ infected & \\
\hline Prior to study & - & - & 0.48 & $32.3 \%$ & - & - & 25 \\
\hline Treatment A & 81.3 & \pm 3.03 & 0.70 & $60.0 \%$ & 0.47 & $36.7 \%$ & 30 \\
\hline Treatment B & 78.5 & \pm 2.53 & 0.83 & $70.0 \%$ & 0.40 & $40.0 \%$ & 30 \\
\hline Treatment C & -72.3 & \pm 2.26 & 0.37 & $66.7 \%$ & 0.33 & $30.0 \%$ & 30 \\
\hline Treatment D & 74.8 & \pm 3.15 & 0.53 & $53.3 \%$ & 0.30 & $30.0 \%$ & 30 \\
\hline
\end{tabular}
details 
$(\mathrm{R} \times \mathrm{C})$ test of independence using the $G$-statistic was used to determine if level of infection (C) was dependent on treatment (R) (Sokal \& Rohlf 1981). The hypothesis tested was based on the marginal totals for infection intensity. Additionally, a Kolmogorov-Smirnov Two-Sample test was done to determine whether distributions among treatments (weighted incidence of infection) were significantly different. The hypothesis tested was that WI in parasitized oysters was the same as that of nonparasitized controls. Perkinsus marinus data collected for 4 mo prior to the parasitism experiment on oysters from the original population as that of the treatments (M. Y. Bobo, South Carolina Wildlife and Marine Resources, pers. comm.), indicated a mean infection intensity and WI of 0.48 (Mackin scale 0 to 6) and $32.3 \%$ respectively (Table 2 ). There was no significant difference in susceptibility to disease due to Boonea impressa parasitism ( $G$-test, $\mathrm{p}>0.05$ ). This was tested using the intrinsic frequency of infection intensity of all treatment populations and testing to see if treatments significantly diverged from the expected value. A Komogorov-Smirnov 2-sample test with 2sided probabilities showed no significant difference between treatments $(\mathrm{p}>0.05)$ for WI.

Comparisons among treatments for shell deposition rates prior to, during and after parasitism were analyzed by nonparametric multiple comparisons using stepwise test procedures (STP). Comparison of shell deposition rate for each treatment for the parasitism period was analyzed using Mann-Whitney $U$-tests. Prior to parasitism all treatments exhibited similar shell deposition rates (Fig. 1). However, by the end of the parasitism period, Treatment D (30 snails per oyster) had a significantly $(p<0.01)$ lower shell deposition rate than other treatments (Table 1). Treatments A, B, and C were not significantly different from the pre-parasitism control after parasitism (Table 1). During the parasitism period Treatment B (screened control) had the highest rate of shell deposition, Treatment D the lowest, with Treatments A (unscreened control) and C (10 snails per oyster) between the extremes (Fig. 1).

\section{DISCUSSION}

Both pre- and post-parasitism analyses showed a high degree of variation associated with measuring net production under natural conditions. All net production values $\left(\mathrm{J} \mathrm{d}^{-1}\right)$ were an order of magnitude above that predicted by White et al. (1988a). For example, they predicted that a subtidal oyster with a mean height of $80 \mathrm{~mm}$ would have a daily net production of $246.1 \mathrm{~J} \mathrm{~d}^{-1}$. Non-parasitized oyster net production ranged from $2786 \mathrm{~J} \mathrm{~d}^{-1}$ (Post-treatment A) to $4123 \mathrm{~J} \mathrm{~d}^{-1}$ (pre-parasitism control). This order of magnitude discrepancy was probably due to significantly higher POM values and overestimated daily ingestion rates measured in our experiment. Overestimation of ingestion rates was due to production of pseudofeces (particles cleared from suspension but rejected prior to ingestion) for each analysis. Therefore, the amount of POM cleared from suspension does not represent the amount of energy ingested by the oyster, but rather is an approximation of the oysters' ecological efficiency (Bayne et al. 1985). The effect of adult Boonea impressa parasitism at different densities was predicted by White et al. (1988a). Using their estimation for adult snail ingestion $\left(4.06 \mathrm{~J} \mathrm{~d}^{-1}\right)$, it was calculated that net production for an $80 \mathrm{~mm}$ oyster, parasitized by 10 and 30 adult B. impressa, would decrease by $16 \%$ and $49.5 \%$ respectively. No claims to loss in energy due to $B$. impressa ingestion can be made from our study because of the difficulty in estimating true production values discussed above. It is clear, however, that net production values measured in terms of ecological efficiency are more a function of food availability than of ecto-parasitism by $B$. impressa. Choi et al. (1989) calculated the amount of energy extracted from the oyster by Perkinsus marinus cells at different intensities of infection. Because of very light infection intensities observed in our treatment populations, $P$. marinus can be eliminated as a significant cost on the energy budget of Crassostrea virginica during the parasitism period and was not a factor in our study.

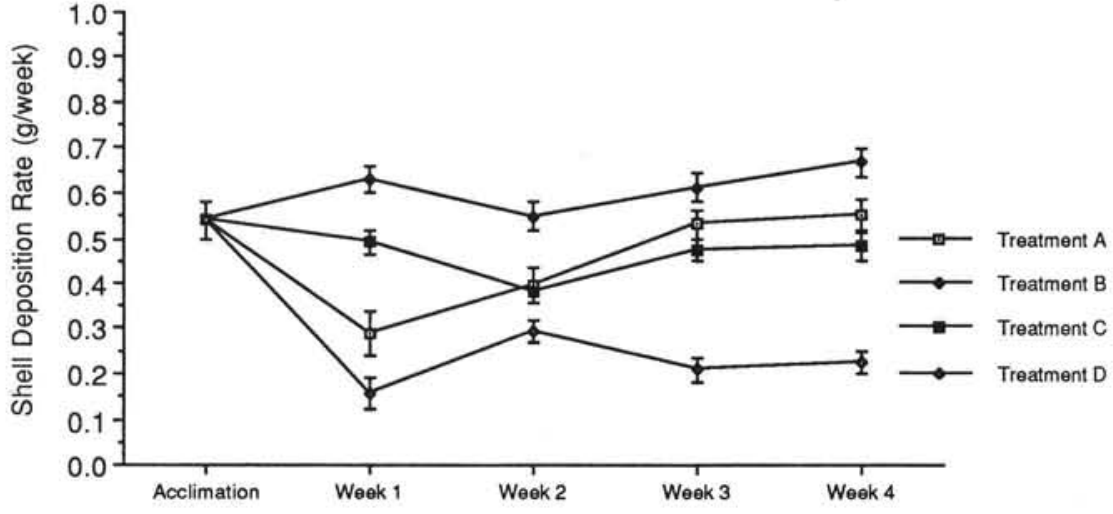

Fig. 1. Crassostrea virginica. Rates of shell deposition $\left(\mathrm{g} \mathrm{wk}^{-1}\right)$ and standard errors for each treatment during the acclimation and parasitism period. Treatment $\mathrm{A}=$ unscreened control; Treatment $B=$ screened control; Treatment $C=10$ snails per oyster; and Treatment $\mathrm{D}=30$ snails per oyster 
Effects of Boonea impressa parasitism can be assessed through the physiological measurements made in our study. Total pre-parasitism respiration was calculated to be $481.5 \mathrm{~J} \mathrm{~d}^{-1}$. White et al. (1988a) predicted respiration rates to be $330.4 \mathrm{~J} \mathrm{~d}^{-1}$, a difference of $151.1 \mathrm{~J} \mathrm{~d}^{-1}$ or ca $6.3 \mathrm{~J} \mathrm{~h}^{-1}$. Oyster respiration rates were not affected by past parasitism of $B$. impressa. The general increase in respiration rate for all treatments after parasitism was attributed to increasing temperatures (Fig. 2). Data concerning the effects of temperature and salinity on oxygen uptake in whole oysters is sparse (Shumway 1982). Even less data exist concerning the effect parasites may have on oyster respiration. Newell (1985) found no difference in the rate of oxygen consumption due to MSX infection in Crassostrea virginica, yet found significant differences in condition index. Data presented here suggest that ectoparasitic parasitism does not hinder respiration in C. virginica on a short-term basis. Since Perkinsus marinus was not a significant factor in this experiment, no conclusion concerning the effect this intercellular parasite had on respiration can be made. Other measurements we made also support the insignificance of previous B. impressa parasitism on oyster metabolism. There were no differences in clearance rates attributed to parasitism (by either $B$. impressa or $P$. marinus), Ward \& Langdon (1986) found that B. impressa interfered with feeding, but noted how quickly clearance rates were restored after $B$. impressa were removed from $C$. virginica. These studies, along with our results, give strong evidence that $C$. virginica recovers rapidly from the effects of ectoparasitic feeding.

Ward \& Langdon (1986) conclude that Boonea impressa parasitism resulted in a significant decline in

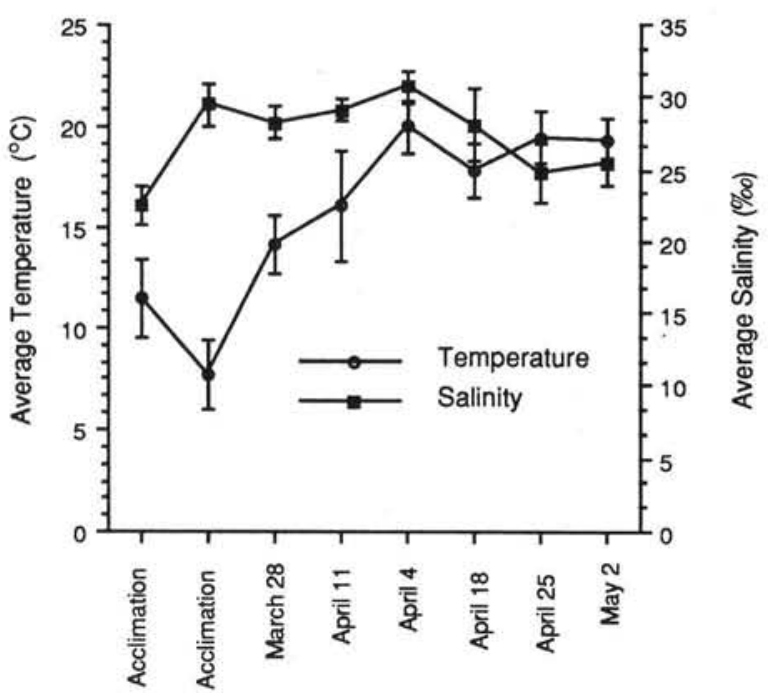

Fig. 2. Salinity and temperature with standard deviations during the $10 \mathrm{~d}$ acclimation and 1 mo parasitism period oyster net production under non-limiting conditions to the oyster in the laboratory. This criterion was based on a seston concentration of $4 \%$ of the whole wet weight of the largest oyster (Urban et al. 1983). A unicellular diet of Isochrysis galbana totaling $4.02 \mathrm{mg} \mathrm{l}^{-1}$ for the 2 wk parasitism experiment and $2.01 \mathrm{mg} \mathrm{l}^{-1}$ for the clearance rate analysis was used by Ward \& Langdon (1986). The former value is on the threshold of pseudofecal production and the latter well below (Haven \& Morales-Alamo 1966). The estimated loss of energy in Crassostrea virginica parasitized by 3 and 6 B. impressa per oyster was calculated to be $49 \%$ and $96 \%$ respectively and was attributed to both snail ingestion of assimilated energy and physical hindrance to the oyster. Their study demonstrated the effect $B$. impressa parasitism can have on oyster net production even at very low densities of ecto-parasitism. However, it may well be that seston became limiting due to snail parasitism per se. If seston concentrations under natural conditions were near a limiting value (where net production $\mathrm{J} \mathrm{h}^{-1}=0$ ), interference of normal oyster filtering due to parasitism by $B$. impressa could lower the threshold value further. There is evidence to suggest that food limitation is an important factor during some periods of the year (Soniat \& Ray 1985, Powell et al. 1987b). Ward \& Langdon (1986) would likely have had non-significant results for both growth and filtration rates if they had used total seston concentrations similar to that in the Charleston estuary during our parasitism study. However, we believe their findings demonstrate that if seston concentrations are on the threshold of being limiting, $B$. impressa can have a significant negative effect on its host's energy budget, even at very low snail densities. The significant increase in net growth efficiency after parasitism in Treatment $\mathrm{D}$ is due to proportionally greater amounts of ingested POM $\left(\mathrm{g} \mathrm{l}^{-1}\right)$ after parasitism (Table 1). Since there was no significant increase in the loss of energy (respiration and excretion) between treatments, a greater amount of energy was put into net production in Treatment D.

Data for condition index showed no significant differences among treatments and supports the findings of Wilson et al. (1988). Newell (1985) found that the condition indices of Crassostrea virginica with systemic infections of Haplosporidium nelsoni (MSX) were significantly reduced compared to oysters without the parasite. Since treatments in our study had no significant differences in infection intensities (very light infections) of Perkinsus marinus, only the effect of parasitism by Boonea impressa could be elucidated in our study. It is probable that the slight increases in both weighted incidence $(W I)$ of infection and percent infected in treatment populations were due to elevated temperatures (Fig. 2). Crosby \& Roberts (1990) have 
demonstrated a significant correlation for $W I$ and percent infected with temperature in South Carolina oyster populations. Our results indicate that short-term parasitism by $B$. impressa, during times of non-limiting seston concentrations and moderate temperatures (ca 18 to $22^{\circ} \mathrm{C}$ ), did not make the oyster increasingly susceptible to $P$. marinus infection. If the alternative were true, one would expect to see higher infection intensities in treatments subjected to $B$. impressa parasitism.

Perkinsus marinus infection intensity generally increases throughout the late summer and fall (Andrews 1988, Andrews \& Ray 1988). In the summer, when water temperatures are high, infected Boonea impressa may contribute to increased infection intensities observed in oysters. The fact that $P$. marinus infection was present in very low densities for all treatments supports the idea that $B$. impressa parasitism, under conditions of low temperature $\left(<20^{\circ} \mathrm{C}\right)$ and nonlimiting seston concentrations, has no significant effect on the long-term nutrient state of young Crassostrea virginica. The idea that increased levels of $P$. marinus infection could significantly reduce both growth and fecundity, as well as increase mortality has been investigated by a number of researchers (Menzel \& Hopkins 1955, Mackin 1962, Burrell et al. 1984, Wilson et al. 1988). In South Carolina, Burrell et al. (1984) found no correlation between gametogenic stage and incidence or intensity of $P$. marinus infection. Using the index of Burrell et al. (1984), developed specifically for South Carolina oysters, we observed no discernible differences in gonadal stage among treatments. This result is not surprising due to the low infection intensities of $P$. marinus in treatment oysters. Andrews \& McHugh (1956) noted that South Carlina oysters have some natural tolerance to $P$. marinus infection. Oysters in the Charleston estuary are susceptible to $P$. marinus infection', yet they have displayed a high resistance to mortality due to $P$. marinus infection (Burrell et al. 1984). Susceptibility and resistance determine host-parasite compatibility and are the result of various innate and acquired resistance mechanisms in the host (Feng 1988). We speculate that in addition to fluctuating salinity (extrinsic factor) and dribble spawning (extrinsic and intrinsic mechanisms), non-limiting seston concentrations throughout the year (i.e. a surplus of available energy to the oyster) are determining factors for the high tolerance of $P$. marinus infection in the Charleston estuary.

Oysters in all treatments were depositing shell which indicates that net production was above a maintenance state. However, there was a significant decrease in

\footnotetext{
- Susceptibility and insusceptibility is defined here as whether or not a host can fulfill the nutritional needs of a parasite (see Read 1958, Feng 1988)
}

shell deposition rate for Treatment $\mathrm{D}$ during the parasitism period. It is likely that this reduction was due to 3 factors. First, physical hindrance by Boonea impressa on oyster valve movement kept parasitized oysters from feeding as often as unparasitized oysters. Second, on numerous occasions $B$. impressa were observed wedged between the oyster valves and were assumed to be feeding on Crassostrea virginica. Thirdly, physical breakage of newly deposited shell was evident and contributed to shell deposition rates being significantly lower for Treatment $\mathrm{D}$. The loss of newly deposited shell may be of significance when modeling the energy flow within oyster reef communities. However, it should be noted that White et al. (1984) discovered that shell deposition rates of parasitized oysters returned quickly to pre-parasitism rates after $B$. impressa were removed.

During the third week of parasitism mucoidal masses were observed on most parasitized oyster valves. Upon examination under a light microscope the masses were identified to be Boonea impressa eggs under various stages of development. B. impressa lives ca 1 yr (Wells 1959, White et al. 1985) and it is not uncommon for reproduction to take place during the time period of our study.

There is no evidence in the literature to suggest that feeding behavior of Boonea impressa is altered during reproduction. During Weeks 3 and 4 of our study, snails were still observed on the outer ridges of oyster valves and were assumed to be feeding. However, if snail behavior is altered during reproduction (e.g. reduced feeding) this could reduce the potential negative effect of snail parasitism on Crassostrea virginica. Powell et al. (1987b) note that B. impressa shifts its prey selection from the slipper limpet Crepidula plana to $C$. virginica as the snail grows in height. This change in food items is not uncommon in many gastropods (Kitting 1984) and may be an adaptation to minimize intraspecific competition between juvenile and adult $B$. impressa.

Acknowledgements. The authors thank the South Carolina Wildlife and Marine Resource Division for use of its space and facilities, M. Y. Bobo for advice and assistance in preparing Perkinsus marinus cultures, the Slocum-Lunz Foundation for financial support, and 2 anonymous reviewers of this manuscript for their insightful criticism. M. P. Crosby also thanks both the Belle W. Baruch Foundation and the Belle W. Baruch Institute for their financial support of this study.

\section{LITERATURE CITED}

Andrews, J. D. (1955). Notes on fungus parasites of bivalve mollusks in Chesapeake Bay. Proc. natn. Shellfish. Ass. 45: $157-163$

Andrews, J. D. (1961). Measurement of shell growth in oysters by weighing in water. Proc. natn. Shellfish. Ass. 52: 1-12 Andrews, J. D. (1965). Infection experiments in nature with 
Dermocystidium marinum in Chesapeake Bay. Chesapeake Sci. 16 (1): 60-67

Andrews, J. D. (1967). Interaction of two diseases of oysters in natural waters. Proc. natn. Shellfish. Ass. 57: 38-49

Andrews, J. D. (1980). Perkinsus marinus $=$ Dermocystidium marinum ('Dermo') in Virginia, 1950-1980. Va. Inst. Mar. Sci. Data report No. 16., 64 pp.

Andrews, J. D. (1988). Epizootiology of the disease caused by the oyster pathogen Perkinsus marinus and its effects on the oyster industry. Am. Fish. Soc. spec. Pub. 18: 47-63

ndrews, J. D., McHugh, J. L. (1956). The survival and growth of South Carolina seed oysters in Virginia waters. Proc. natn. Shellfish. Ass. 47: 3-17

Andrews, J. D., Ray, S. M. (1988). Management strategies to control the disease caused by Perkinsus marinus. Am. Fish. Soc. Sp. Pub. 18: 257-264

Bayne, B. L., Brown, D. A., Burns, K., Dixon, D. R., Ivanovici, A., Livingstone, D. R., Lowe, D. M., Moore, M. N., Stebbing, A. R. D., Widdows, J. (1985). The effects of stress and pollution on marine animals. Praeger, Greenwood Press, Westport, Connecticut

Burrell, V. G. Jr, Bobo, M. Y., Manzi, J. M. (1984). A comparison of seasonal incidence and intensity of Perkinsus marinus between subtidal and intertidal oyster populations in South Carolina. J. World Maricult. Soc. 15: 301-309

Choi, K. S., Wilson, E. A., Lewis, D. H., Powell E. N., Ray, S. M. (1989). The energetic cost of Perkinsus marinus parasitism in oysters, quantification of the fluid thioglycollate method. J. Shellfish. Res. 8 (1): 125-137

Conover, R. J. (1966). Assimilation of organic matter by zooplankton. Limnol. Oceanogr. 11: 338-354

Crosby, M. P., Gale, L. D. (1990). A review and evaluation of bivalve condition index methodologies with a suggested standard method. J. Shellfish. Res. 9 (1): 233-237

Crosby, M. P., Roberts, C. F. (1990), Seasonal infection intensity cycle of the parasite Perkinsus marinus (and an absence of Haplosporidium spp.) in oysters from a South Carolina salt marsh. Dis. aquat. Org. 9: 149-155

Feng, S. Y. (1988), Cellular defense mechanisms of oysters and mussels. Am Fish. Soc. spec. Pub., 18: 153-168

Galstoff, P. S. (1964). The American oyster, Crassostrea virginica, (Gmelin). Fish. Bull. Fish Wildl. Serv. U.S. 64 : 1-480

Haven, D. S., Morales-Alamo, R. (1966). Aspects of biodeposition by oysters and other invertebrate filter feeders. Limnol. Oceanogr. 11: 487-498

Hopkins, S. (1956). Odostomia impressa parasitizing southern oysters. Science 124: 628-629

Kitting, C. L. (1984). Selectivity by dense populations of small invertebrates foraging among seagrass blade surfaces. Estuaries 7 (4A): 276-288

Mackin, J. G. (1962). Oyster disease caused by Dermocystidium marinum and other microorganisms in Louisiana. Publ. Inst. Mar. Sci. Univ. Tex. 7: 132-229

Mackin, J. G., Owen, H. M., Collier A. (1950). Preliminary note on the occurrence of a new protistan parasite, Dermocystidium marinum n. sp. in Crassostrea virginica, (Gmelin). Science 111: 328-329

Mackin, J. G., Wray, D. A. (1950). Report on the second study of mortality of oysters in Barataria Bay, Louisiana, and adjacent areas. Part I. Pub. Inst. Mar. Sci. Univ. Tex. 9, $46 \mathrm{pp}$.

Mackin, J. G., Wray, D. A. (1952). Report on the second study of mortality of oysters in Barataria Bay, Louisiana, and adjacent areas. Part II. Pub. Inst. Mar. Sci. Univ. Tex. 9, $43 \mathrm{pp}$.

Menzel, R. W., Hopkins, S. H. (1955). Effects of two parasites on the growth of oysters. Proc. natn. Shellfish. Ass. 45: 184-186

Newell, R. I. E. (1985). Sublethal physiological effects of the parasite MSX (Haplosporidium nelsoni) on the oyster Crassostrea virginica. J. Shellfish Res. 5: 91-95

Newell, R. I. E., Barber, B. J. (1988), A physiological approach to the study of bivalve diseases. Am. Fish. Soc. spec. Pub. 18: 23-37

Perkins, F. O. (1976). Dermocystidium marinum infection in oysters. Mar. Fish. Rev. 38 (10): 19-21

Powell, E. N., Stanton, R. J. Jr (1985). Estimating biomass and energy flow of molluscs in palaeo-communities. Paleontology (London) 28: 1-34

Powell, E. N., White, M. E., Wilson, E. A., Ray, S. M. (1987a). Small-scale spatial distribution of a pyramidellid snail ectoparasite, Boonea impressa, in relation to its host, Crassostrea virginica, on oysters reefs. P.S.Z.N.I.: Mar. Ecol. 8 (2): 107-130.

Powell, E. N., White, M. E., Wilson, E. A., Ray, S. M. (1987b). Change in host preference with age in the ectoparasitic pyramidellid snail Boonea impressa (Say). J. Mollusc. Stud. 53: 285-286

Quick, J. A., Mackin, J. G. (1971). Oyster parasitism by Labyrinthomyxa marina in Florida. Florida Dept. Natural Res. Prof. Pap. Ser. No. 13

Ray, S. M. (1953). Studies on the occurrence of Dermocystidium marinum (Mackin, Owen, and Collier) in young oysters. Proc. natn. Shellfish. Ass. 43: 80-88

Ray, S. M. (1954). Biological studies of Dermocystidium marinum, a fungus parasite of oysters. Rice Inst. Pamph. Special Issues, November 1954, $114 \mathrm{pp}$.

Ray, S. M. (1966). A review of the culture method for detecting Dermocystidium marinum, with suggested modifications and precautions. Proc. natn. Shellfish. Ass. 54: 55-69

Read, C. P. (1958). Status of behavioral and physiological 'resistance'. Rice Institute Pamphlet 45: 36-54

Scott, G. I., Middaugh, D. P., Sammons, T. I. (1985). Interactions of chlorine-produced oxidants $(\mathrm{CPO})$ and salinity in affecting lethal and sublethal effects in the Eastern or American oyster Crassostrea virginica (Gmelin), infected with the protistan parasite, Perkinsus marinus. In: Vernberg, J. F., Thurberg, F. P., Calabrese, A., Vernberg, W. B., (eds.) Pollution and physiology: recent advances. Univ. of South Carolina Press, Columbia, p. 351-376

Shumway, S. E. (1982). Oxygen consumption in oysters: an overview. Mar. Biol. Lett. 3: 1-23

Sokal, R. R., Rohlf, F. J. (1981). Biometry, 2nd edn. W. H. Freeman and Co., New York

Solorzano, L. (1969). Determination of ammonia in natural waters by the phenolhypochlorite method. Limnol. Oceanogr. 14: 799-801

Soniat, T. M., Koenig, M. L. (1982). The effects of parasitism by Perkinsus marinus on the free amino acid composition of Crassostera virginica mantle tissue. J. Shellfish Res. 2: 25-28

Soniat, T. M., Ray, S. M. (1985). Relationships between possible available food and the composition, condition and reproductive state of oysters from Galveston Bay, Texas. Contrib. mar. Sci. 28: 109-121

Sprague, V. (1954). Protozoa. Gulf of Mexico, its origin, waters, and marine life. Fish. Bull. U.S. 89 (55): 243-256

Thompson, R. J., Bayne, B. L. (1974). Some relationships between growth, metabolism and food in the mussel, Mytilus edulis. Mar. Biol. 27: 317-326

Urban, E. R. Jr, Pruder, G. D., Langdon, C. J. (1983). Effects of ration on growth and growth efficiency of juveniles of Crassostrea virginica, (Gmelin). J. Shellfish. Res. 3: 51-57

Ward, J. E., Langdon, C. J. (1986). Effects of the ectoparasitic 
Boonea (= Odostromia) impressa (Say) (Gastropoda: Pyramidellidae) on the growth ra filtration rate, and valve movements of the host (Crassostera virginica) (Gmelin). J. exp. mar. Biol. Ecol. 99: 163-180

Wells, H. (1959). Notes on Odostomia impressa (Say). Nautilus 72: $140-144$

White, M. E., Kitting, C. L., Powell, E. N. (1985). Aspects of reproduction, larval development, and morphometrics in the Pyramidellid Boonea impressa (=Odostomia impressa) (Gastropoda: Opisthobranchia). Veliger 28 (1): 37-51

White, M. E., Powell, E. N., Kitting, C. L. (1984). The ectoparasitic gastropod Boonea (= Odostomia) impressa: population ecology and the influence of parasitism on oyster growth rates. Mar. Ecol. 5 (3): 283-299

White, M. E., Powell, E. N., Ray, S. M., Wilson, E. A. (1987). Host-to-host transmission of Perkinsus marinus in oyster

This article was presented by F. J. Vernberg, Columbia, S. Carolina, USA
(Crassostera virginica) populations by the ectoparasitic snail Boonea impressa (Pyramidellidae). J. Shellfish. Res. 6 (1): $1-5$

White, M. E., Powell, E. N., Ray, S. M. (1988a). Effect of parasitism by the pyramidellid gastropod Boonea impressa on the net productivity of oysters (Crassostera virginica). Estuar. coast. Shelf Sci. 26: 359-377

White, M. E., Powell, E. N., Ray, S. M., Wilson, E. A., Zastrow, C. E. (1988b). Metabolic changes induced in oysters (Crasostera virginica) by the parasitism of Boonea impressa (Gastropoda: Pyramidellidae). Comp. Biochem. Physiol. 90A (2): 279-290

Wilson, E. A., Powell, E. N., Ray, S. M. (1988). The effect of the ectoparasitic pyramidellid snail, Boonea impressa, on the growth and health of oysters, Crassostera virginica, under field conditions. Fish. Bull. U.S. 86 (3): 553-566

Manuscript first received: March 15, 1991

Revised version accepted: November 7, 1991 